\title{
PENGARUH METODE WEBQUAL 4.0 TERHADAP KEPUASAN PENGGUNA WEBSITE POLITEKNIK NEGERI SRIWIJAYA
}

\section{THE IMPACT OF WEBQUAL 4.0 METHOD TOWARDS USER SATISFACTION OF POLITEKNIK NEGERI SRIWIJAYA WEBSITE}

\author{
Agnes Manik $^{1}$, Irma Salamah $^{2}$, Eka Susanti $^{3}$ \\ ${ }^{123}$ Program Studi Teknik Telekomunikasi Politeknik Negeri Sriwijaya, \\ Jl Srijaya Negara, Bukit Besar, Ilir Barat 1, Kota Palembang, \\ Sumatera Selatan

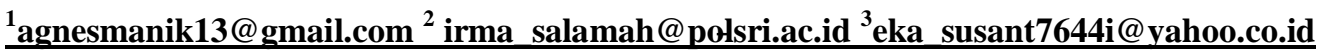

\begin{abstract}
Abstrak
Website merupakan salah satu bentuk media masa yang dipublikasi melalui jaringan internet yang dapat diakses dimanapun dan kapanpun. Untuk mengetahui kualitas sebuah Website maka perlu dilakukan pengukuran. Dengan melakukan pengukuran kualitas suatu Website dapat diketahui persepsi pengguna terhadap Website tersebut. Dalam penelitian ini menggunakan metode WebQual yang telah dimodifikasi dengan menambahkan dimensi kepuasan pengguna dengan tiga dimensi utama WebQual 4.0, yaitu Usability, Information, Service Interaction. Penelitian ini dilakukan di lingkungan Politeknik Negeri Sriwijaya. Penelitian ini dilakukan dengan menggunakan kuesioner. Populasi dari penelitian ini adalah mahasiswa Politeknik Negeri Sriwijaya. Hasil yang diperoleh pada penelitian ini adalah perkembangan Website yang lebih baik, didapat bahwa kualitas kegunaan dan kualitas informasi berpengaruh positif terhadap kepuasan pengguna. Kualitas layanan interaksi berpengaruh negatif terhadap kepuasan pengguna website Politeknik Negeri Sriwijaya.
\end{abstract}

Kata kunci: kualitas informasi, kualitas layanan interaksi, kualitas kegunaan, website

\begin{abstract}
Website is one form of mass media that published through internet network that can be accessed wherever and whenever. To be able to get a quality website must be done. By measuring the quality of a website, it can be known the user's perception of the website. In this study using WebQual method that has been modofied with the addition the dimension of user satisfactionwith the three main dimensions of WebQual 4.0 usability, information, service interaction. This research was conducted in the environment of State Polytechnic of Sriwijaya. This research was conducted by using questionnaire. The population of this research is State Polytechnic of Sriwijaya collegers. The result obtained in this study is the development of a better website, it is found that the quality of information and quality of usability affects positive on user satisfaction. Quality of service interaction affects a negative on the usersatisfaction of State Polytechnic of Sriwijaya user.
\end{abstract}

Keywords: Information quality, usability quality, service interaction quality and user satisfaction

\section{PENDAHULUAN}

Pesatnya perkembangan teknologi informasi dan komunikasi telah menjadikan informasi sangat mudah untuk diakses melalui berbagai saluran komunikasi terutama pada institusi akademik dalam berbagai macam cara (Santoso dan Anwar, 2015). Kemajuan teknologi internet kini telah menjadi simbol cara berkomunikasi secara bebas, tanpa dibatasi oleh ruang, jarak dan waktu. Didukung berbagai kelebihan dan keunggulan dari internet, antara lain adalah biaya koneksi 
internet yang relatif terjangkau dan ketersediaan informasi yang tak terbatas, internet saat ini menjadi salah satu kebutuhan utama masyarakat dalam memenuhi segala kebutuhan yang terkait dengan informasi (Nurhayati, 1998).

Website atau World Wide Web (WWW) adalah salah satu media penting dimana pengguna dapat menemukan semua jenis informasi yang berkaitan dengan bidang mereka sendiri merupakan salah satu bentuk media masa yang dipublikasi melalui jaringan internet yang dapat diakses dimanapun dan kapanpun (Monalisa, 2016). Maka dari itu kelebihan website inilah yang kini banyak dikembangkan oleh berbagai institusi pendidikan yang menjadi sebuah sistem informasi akademik dan dapat diakses secara online di mana salah satunya adalah Politeknik Negeri Sriwijaya. Politeknik Negeri Sriwijaya memiliki layanan informasi dan berita melalui internet dalam bentuk pengadaan situs www.polsri.ac.id yang dirancang khusus oleh pihak manajemen pengelola dalam memberikan pelayanan yang lebih baik kepada mahasiswa. Menyadari hal itu, maka website POLSRI harus bisa meningkatkan kualitas website. Maka dari itu, penulis perlu menentukan kualitas website dengan melakukan pengukuran menggunakan metode WebQual (Irawan, 2012). Melihat kenyataan tersebut desain sebuah website merupakan salah satu kunci sukses suatu lembaga yang ingin mengimplementasikan konsep dalam pendidikan. Sehingga, penting bagi menajemen dan praktisi teknologi informasi untuk mengetahui kriteria apa saja yang harus dipertimbangkan dalam mendesain dan mengembangkan website. Suatu website yang baik juga memiliki kelayakan sebagai media yang bermanfaat. Untuk mengetahui kelayakan tersebut dilakukan pengukuran dengan menggunakan metode WebQual (Wahidin Abbas, 2013).

Metode WebQual merupakan salah satu teknik pengukuran untuk menentukan kualitas website. Metode WebQual menggunakan pendekatan perception dan importance dari pengguna. Persepsi penggguna tentang suatu sistem informasi yang baik adalah sistem yang dimana pengguna merasa puas dengan kualitas dari website. Kualitas ini termuat dalam tiga dimensi dari WebQual versi 4.0. WebQual mengukur mutu website berdasarkan persepsi dari pengguna website. Maka pengukurannya menggunakan instrument penelitian atau kuesioner (S. Barnes and R. Vidgen, 1998).

\section{TINJAUAN PUSTAKA}

\subsection{Website}

World Wide Web (WWW) atau biasa disebut dengan website, merupakan salah satu sumber daya internet yang berkembang pesat. Informasi Website disebarluaskan melalui hypertext (suatu cara untuk menghubungkan berbagai dokumen di internet), yang dapat memungkinkan suatu teks pendek menjadi acuan untuk membuka dokumen yang lainnya. Dengan pendekatan hypertext ini seseorang mendapatkan informasi dengan meloncat dari satu dokumen ke dokumen yang lain Nurhayati, (1998).

\subsection{WEBQUAL 4.0}

WebQual 4.0 merupakan hasil analisis pada WebQual 3.0 yang membawa pada identifikasi tiga dimensi dari kualitas website e-commerce, yaitu: kegunaan (usability), kualitas informasi (information quality) dan kualitas layanan interaksi (service interaction quality). Dalam WebQual 4.0 ini, kegunaan berkaitan dengan desain website misalnya penampilan, kemudahan penggunaan, navigasi dan juga tampilan yang disampaikan dalam website tersebut. Kegunaan fokus pada pandangan bagaimana pengguna melihat dan berinteraksi dengan website: apakah mudah bernavigasi? Apakah desain sesuai dengan jenis website? Lalu kualitas informasi merupakan kualitas dari isi website, yaitu kesesuaian informasi untuk penggunanya seperti format, tingkat akurasi dan juga relevansi. Terakhir ada kualitas layanan interaksi yang merupakan hal yang dialami oleh pengguna website, diwujudkan dalam bentuk kepercayaan dan empati misalnya mengenai transaksi dan keamanan informasi, pengiriman produk, personalisasi dan komunikasi dengan pemilik atau pengelola website 


\section{A. Usability Quality}

Usability adalah mutu yang berhubungan dengan rancangan site, sebagai contoh penampilan, kemudahan penggunaan, navigasi dan gambaran yang disampaikan kepada pengguna. Menurut Barnes, kualitas informasi meliputi hal - hal seperti informasi yang akurat, informasi yang bisa di percaya, informasi yang up to date atau terbaru, informasi yang sesuai dengan topik bahasan, informasi yang mudah dimengerti, informasi yang sangat detail dan mendalam, dan informasi yang disajikan dalam format desain yang sesuai Sekaran (2003).

Berikut ini tiga komponen umum usability:

1. Adanya keterlibatan seorang pengguna,

2. Pengguna melakukan suatu pekerjaan, dan

3. Pengguna melakukan sesuatu dengan adanya produk, sistem atau hal

\section{B. Information Quality}

Kulitas informasi dari penelitian sistem informasi (Information Quality) Information Quality adalah mutu dari isi yang terdapat pada site, pantas tidaknya informasi untuk tujuan pengguna seperti akurasi, format dan keterkaitannya.

\section{Service Interaction Quality}

Service Interaction Quality adalah mutu dari interaksi pelayanan yang dialami oleh pengguna ketika mereka menyelidiki kedalam site lebih dalam, yang terwujud dengan kepercayaan dan empati, sebagai contoh isu dari keamanan transaksi dan informasi, pengantaran produk, personalisasi dan komunikasi dengan pemilik site.

\subsection{Metode Analisis Data}

Agar suatu data yang dikumpulkan dapat bermanfaat, maka harus diolah dan dianalisis terlebih dahulu sehingga dapat dijadikan dasar pengambilan keputusan. Tujuan metode analisis data adalah untuk menginterprestasikan dan menarik kesimpulan dari sejumlah data yang terkumpul.

\section{A. Uji Validitas}

Item yang mempunyai korelasi positif dengan kriterium (skor total) serta korelasi yang tinggi, menunjukkan item tersebut mempunyai validitas yang tinggi pula. Apabila alat ukur tersebut berada $<\mathrm{r}$ tabel (tidak valid) dan $>\mathrm{r}$ tabel (valid). Berdasarkan dari pengertian tersebut maka hal ini dilakukan untuk mengetahui pertanyaan dan pernyataan mana yang valid dan mana yang tidak valid, dengan mengkonsultasikan data tersebut dengan tingkat signifikan $r$ tabel apabila alat ukur tersebut berada $<\mathrm{r}$ tabel (tidak valid). Pengujian statistik mengacu pada kriteria :

- $r$ hitung $<r$ tabel maka tidak valid

- $r$ hitung $>r$ tabel maka valid

Untuk pengujian validitas instrumen penelitian ini, penulis menggunakan program excel dalam tabulasi data dan memasukkan data tersebut ke dalam program SPSS dengan metode Corrected Item Total Correlation.

\section{B. Uji Reliabilitas}

Setelah dilakukan uji validitas atas pertanyaan yang digunakan dalam penelitian tersebut, selanjutnya dilakukan uji keandalan. Uji keandalan bertujuan untuk mengetahui apakah alat pengumpul data pada dasarnya menunjukkan tingkat ketepatan, keakuratan, kestabilan atau konsistensi alat tersebut dalam mengungkapkan gejala tertentu dari sekelompok individual, walaupun dilakukan pada waktu yang berbeda.

Uji keandalan dilakukan terhadap pertanyaan-pertanyaan atau pernyataan-pernyataan yang sudah valid. Reliabilitas menyangkut ketepatan alat ukur. Untuk teknik perhitungan reliabilitas kuesioner yang digunakan dalam penelitian ini adalah dengan menggunakan Statistical Product 
and Service Solution (SPSS) 21 for windows. Item dikatakan reliabel jika nilai Cronbach's Alpha lebih besar dari nilai kritis. Nilai kritis yang ditetapkan adalah 0,6.

- Jika nilai Alpha $>0,6$ maka reliabel

- Jika nilai Alpha <0,6 maka tidak reliabel

\subsection{Uji Asumsi Klasik}

Dalam melakukan analisis regresi dilakukan pula uji asumsi klasik yang terdiri dari Multikolinearitas, Heteroskedastisitas, dan Autokorelasi. Selain itu pastinya diuji pula Normalitas Data sebagai syarat dalam melakukan analisis regresi.

\section{A. Multikolinearitas}

Regresi yang baik mensyaratkan tidak adanya multikolinearitas, untuk mengetahui terjadi atau tidaknya multikolinearitas dengan melihat nilai tolerance dan VIF. Semakin kecil nilai tolerance dan semakin besar nilai VIF maka semakin mendekati terjadinya masalah multikolinearitas. Nilai tolerance lebih dari 0,1 dan VIF kurang dari 10 maka tidak terjadi multikolinearitas.

\section{B. Heterokedastisitas}

Heterokedastisitas adalah mengkorelasi nilai residu hasil regresi dengan masing-masing variabel independen. Nilai signifikan antara variabel independen dengan residual lebih dari 0,05 maka terjadi masalah heterokedastisitas, tetapi jika signifikan kurang dari 0,05 maka terjadi masalah heterokedastisitas.

\section{Autokorelasi}

Autokorelasi merupakan suatu keadaan dimana terjadinya korelasi dari residual untuk pengamatan satu dengan pengamatan yang lain disusun menurut urutan waktu.

\section{Normalitas Data}

Normalitas data digunakan untuk mengetahui apakah data terdistribusi dengan normal atau tidak. Uji ini dilakukan dengan metode Normal Probability Plots. Dasar pengambilan suatu keputusan untuk mendeteksi kenormalan yaitu apabila data menyebar di sekitar garis diagonal dan mengikuti arah diagonal, maka model regresi telah memenuhi asumsi normalitas. Sedangkan apabila data yang dihasilkan menyebar jauh dari garis diagonal atau tidak mengikuti arah diagonal, maka model regresi dinyatakan tidak memenuhi asumsi normalitas.

\subsection{Uji T dan Uji F}

Uji T digunakan untuk menguji variabel independen secara parsial terhadap variabel dependen. Sedangkan uji F untuk menguji pengaruh variabel independen secara bersama-sama terhadap variabel dependen.

\subsection{PEMBAHASAN}

\subsection{Validitas}

Uji validitas menggunakan nilai $r$ tabel dengan signifikansi 0,05. Untuk nilai $r$ tabel dengan $n=100$ maka di dapat $r$ tabel sebesar 0.195 , jadi jika nilai korelasi lebih dari nilai $r$ tabel maka item dianggap valid, sedangkan jika kurang dari batasan yang ditentukan maka item dianggap tidak valid. 
Tabel 1 Validitas Variabel Kualitas Kegunaan (Usability Quality)

\begin{tabular}{|c|c|c|c|c|}
\hline No. & Variabel & r hitung & r kritis & Keterangan \\
\hline $\mathbf{1}$ & X11 & 0,380 & 0,279 & Valid \\
\hline $\mathbf{2}$ & X12 & 0,312 & 0,279 & Valid \\
\hline $\mathbf{3}$ & X13 & 0,405 & 0,279 & Valid \\
\hline $\mathbf{4}$ & X14 & 0,459 & 0,279 & Valid \\
\hline $\mathbf{5}$ & X15 & 0,449 & 0,279 & Valid \\
\hline $\mathbf{6}$ & X16 & 0,420 & 0,279 & Valid \\
\hline $\mathbf{7}$ & X21 & 0,595 & 0,279 & Valid \\
\hline $\mathbf{8}$ & X22 & 0,601 & 0,279 & Valid \\
\hline $\mathbf{9}$ & X23 & 0,618 & 0,279 & Valid \\
\hline $\mathbf{1 0}$ & X24 & 0.681 & 0,279 & Valid \\
\hline $\mathbf{1 1}$ & X25 & 0,630 & 0,279 & Valid \\
\hline $\mathbf{1 2}$ & X26 & 0,711 & 0,279 & Valid \\
\hline $\mathbf{1 3}$ & X27 & 0,518 & 0,279 & Valid \\
\hline $\mathbf{1 4}$ & X31 & 0,646 & 0,279 & Valid \\
\hline $\mathbf{1 5}$ & X32 & 0,599 & 0,279 & Valid \\
\hline $\mathbf{1 6}$ & X33 & 0,611 & 0,279 & Valid \\
\hline $\mathbf{1 7}$ & X34 & 0,554 & 0,279 & Valid \\
\hline $\mathbf{1 8}$ & X35 & 0,496 & 0,279 & Valid \\
\hline $\mathbf{1 9}$ & X36 & 0,584 & 0,279 & Valid \\
\hline $\mathbf{2 0}$ & Y11 & 0,330 & 0,279 & Valid \\
\hline $\mathbf{2 1}$ & Y12 & 0,340 & 0,279 & Valid \\
\hline $\mathbf{2 2}$ & Y13 & 0,582 & 0,279 & Valid \\
\hline $\mathbf{2 3}$ & Y14 & 0,452 & 0,279 & Valid \\
\hline $\mathbf{2 4}$ & Y15 & 0,516 & 0,279 & Valid \\
\hline
\end{tabular}

\subsection{Reliabilitas}

Penelitian kali ini uji reliabilitas yang digunakan adalah metode Cronbach Alpa. Website Polsri dinyatakan memenuhi kriteria reliabitas yang dapat dipercaya. Hasil penelitian kali ini di dapat nilai relibialitas sebagai berikut :

Tabel 2 Reliabilitas semua Variabel

\begin{tabular}{|l|c|c|c|c|}
\hline No & Variabel & Hasil Uji & Syarat & Keterangan \\
\hline $\mathbf{1}$ & Variabel kegunaan & 0,674 & 0,6 & Reliabel \\
\hline $\mathbf{2}$ & Variabel informasi & 0,856 & 0,6 & Reliabel \\
\hline $\mathbf{3}$ & Variabel Interaksi & 0,816 & 0,6 & Reliabel \\
\hline $\mathbf{5}$ & Variabel Kepuasan & 0,681 & 0,6 & Reliabel \\
\hline
\end{tabular}




\subsection{Uji Asumsi Klasik}

\section{A. Multikolinearitas}

Tabel 3 Hasil Uji Multikolinearitas

\begin{tabular}{|l|c|c|c|}
\hline No & Variabel & Tolerance & VIF \\
\hline $\mathbf{1}$ & Variabel kegunaan & 0,407 & 2,459 \\
\hline $\mathbf{2}$ & Variabel informasi & 0,307 & 3,258 \\
\hline $\mathbf{3}$ & Variabel Interaksi & 0,344 & 2,904 \\
\hline
\end{tabular}

Dapat kita lihat nilai tolerance lebih dari 0,1 dan nilai VIF lebih kecil dari 10. Maka tidak terjadi multikolinearitas pada penelitian ini.

\section{B. Heterokedastisitas}

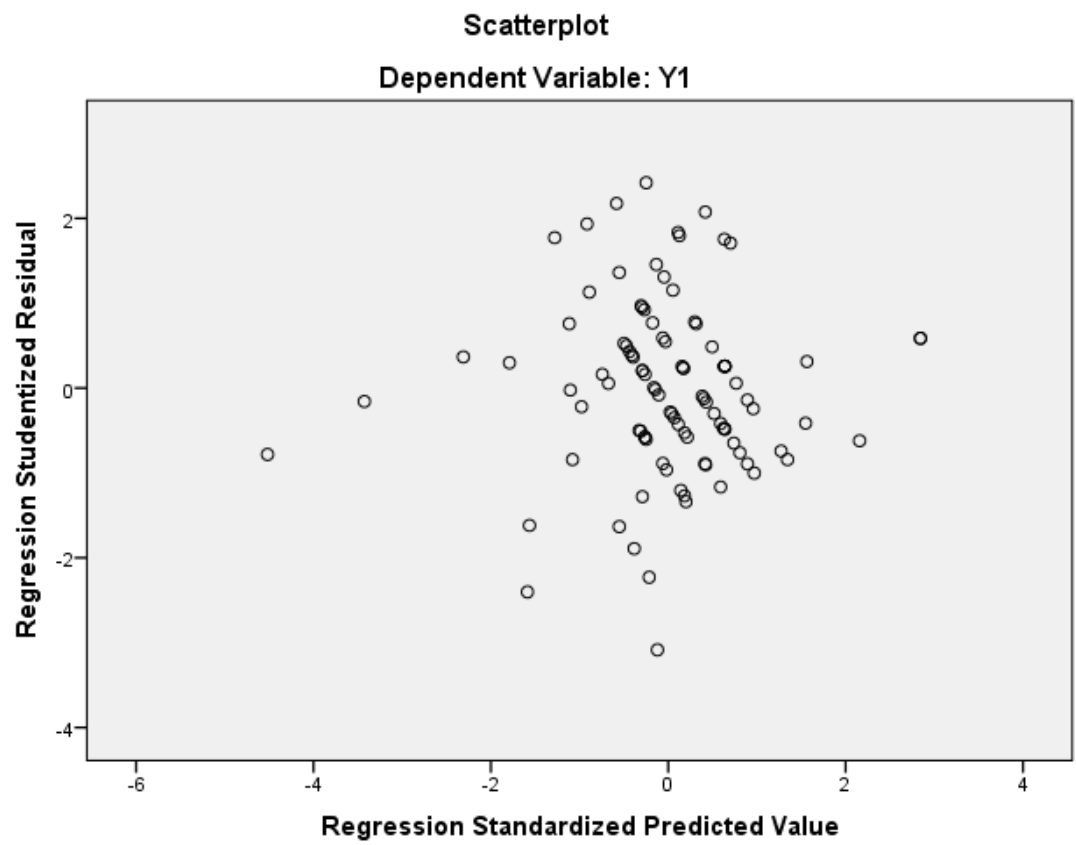

Gambar 1. Hasil Heterokedastisitas dengan Scatter Plot

Hasil pengujian heteroskedastisitas menunjukkan bahwa titik-titik tidak membentuk pola tertentu atau tidak ada pola yang jelas serta titik-titik menyebar di atas dan dibawah angka 0 (nol) pada sumbu Y, maka tidak terjadi heteroskedastisitas. Dengan demikian, asumsi-asumsi normalitas, multikolinearitas dan heteroskedastisitas dalam model regresi dapat dipenuhi dari model ini.

\section{Autokorelasi}

Dari penelitian ini di dapat nilai Durbin Watson sebesar 2,025 dan dari tabel Durbin Watson signifikan 5\% di dapat nilai $\mathrm{dL}=1,592 \mathrm{dU}=1,7584-\mathrm{dL}=2,4084-\mathrm{dU}=2,242$. Sehingga dapat dinyatakan tidak terjadi autokorelasi karna memenuhi syarat $\mathrm{dL}<\mathrm{DW}<4$-dU $(1,759<1,907<2,242)$.

\section{Normalitas Data}

Dapat dinyatakan model regresi pada penelitian ini memenuhi asumsi normalitas karena dilihat dari gambar dibawah ini data menyebar disekitar garis diagonal. 


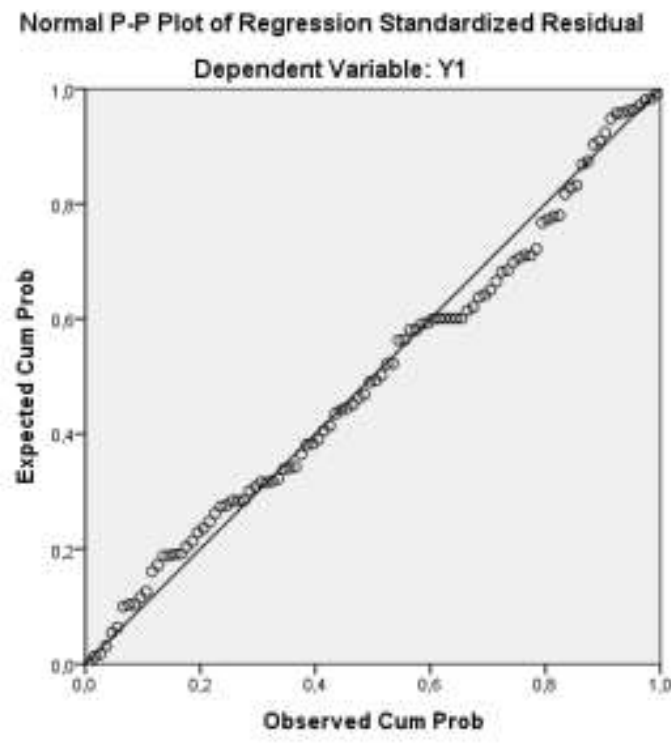

Gambar 2. Hasil Normalitas Data dengan Normal Probability Plots

\subsection{Uji T dan Uji F}

Tabel 4 Hasil Uji Multikolinearitas

\begin{tabular}{|c|c|c|c|}
\hline No & Variabel & T Hitung & T Tabel \\
\hline $\mathbf{1}$ & Variabel kegunaan & 5,586 & 1,675 \\
\hline $\mathbf{2}$ & Variabel informasi & 3,824 & 1,675 \\
\hline $\mathbf{3}$ & Variabel Interaksi & 0,424 & 1,675 \\
\hline
\end{tabular}

Pengaruh variabel kualitas kegunaan, kualitas informasi, kualitas layanan interaksi dan kualitas desain diketahui berdasarkan uji F. F hitung yang didapat sebesar 77,294> nilai F tabel $(2,47)$. Maka dapat dinyatakan bahwa kualitas kegunaan, kualitas informasi, kualitas layanan interaksi dan kualitas desain website Polsri berpengaruh signifikan terhadap kepuasan pengguna.

Pada penelitian kali ini, ada 4 hipotesis sehingga dapat dianalisa bahwa:

(1) hipotesis pertama, didapat koefisien sebesar 0,484 berpengaruh positif terhadap kepuasan pengguna. Hal ini terbukti dari nilai t hitung 5,586 yang lebih besar dari nilai t tabel yaitu 1,675 begitu juga nilai signifikan yaitu 0,000 yang lebih kecil dari tingkat kesalahan sebesar 0,05.

(2) Kemudian hipotesis kedua, didapat koefisien sebesar 0,381 berpengaruf positif terhadap kepuasan pengguna. Hal ini didukung dari nilai t hitung 3,824 yang lebih besar dari nilai t tabel yaitu 1,675 dan nilai signifikan 0,000 yang lebih kecil dari tingkat kesalahan 0,05 .

(3) Hipotesis ketiga, koefisien sebesar 0,040 berpengaruh negatif terhadap kepuasan pengguna. Terbukti dari nilai t hitung 0.424 yang lebih kecil dari nilai t tabel yaitu 1,675 begitu juga nilai signifikan 0,673 yang lebih besar dari tingkat kesalahan yaitu 0,05 .

(4) Secara keseluruhan pengaruh paling dominan terhadap kepuasan pengguna terlihat dari variabel kegunaan sebesar 0,455 . hal ini didukung oleh kualitas kegunaan yang lebih baik yaitu kemudahan menavigasikan website, menambah pengetahuan dan informasi, memiliki link disetiap unit kinerjanya dan memiliki tampilan yang menari dan aktraktif. 


\subsection{KESIMPULAN}

Hasil evaluasi kualitas website terhadap kepuasan pengguna yang telah dilakukan dari penelitian kali ini dapat disimpulkan bahwa :

1. Kualitas kegunaan berpengaruh positif terhadap kepuasan pengguna.

2. Kualitas informasi berpengaruh positif terhadap kepuasan pengguna.

3. Kualitas layanan tidak berpengaruh terhadap kepuasan pengguna.

4. Secara bersamaan kualitas kegunaan, informasi dan layanan berpengaruh postif terhadap kepuasan pengguna.

\section{DAFTAR PUSTAKA}

[1] Santoso dan Anwar.2015. Analisis Kualitas Website Menggunakan Metode WebQual Dan Importance - Performance Analisys ( IPA ) Pada Situs Kaskus."

[2] Nurhayati.1998. Analisa Website Puslit Indonesia Dengan Menggunakan WebQual Untuk Pengukuran Kualitas Website.

[3] S. Monalisa.2016. Analisis Kualitas Layanan Website Terhadap Kepuasan Mahasiswa dengan Penerapan Metode WebQual ( Studi Kasus : UIN Suska Riau.

[4] C. Irawan.2012. Evaluasi Kualitas Website Pemerintah Daerah Dengan Menggunakan WebQual (Studi Kasus Pada Kabupaten Ogan Ilir.

[5] Nurhayati.1998. Analisa Website Puslit Indonesia Dengan Menggunakan WebQual Untuk Pengukuran Kualitas Website.

[6] S. Barnes dan R. Vidgen.1998. WebQual : An Exploration of Web-site Quality.

[7] Wahidin Abbas.2013. Analisa kepuasan Mahasiwa Terhadap Website Universitas Negeri Yogyakarta (UNY).

[8] Sekaran.2003. Metode Penelitian. Edisi Kelima. Jakarta. Ghalia Indonesia.

[9] Ghozali, Imam.2005. Aplikasi Analisis Multivariate dengan SPSS. Semarang, Badan Penerbit UNDIP. 